\title{
GODORT Annual Meeting Reports
}

\section{Report of the GODORT Cataloging Committee Virtual ALA Annual Meeting}

Met on Tuesday June 30, 2020, 11-12 PT / 12-1 MT / 1-2 CT / 2-3 ET

Andie Craley, Chair

1. January 22, 2020, Virtual Midwinter meeting minutes approved.

2. Library Services and Content Management Update (Stephen Kharfen, GPO)

a. Stephen to check with LSCM ILS Projects and Systems Unit and Outreach and Support to add more help resources like tutorials and webinars as part of the FDLP Academy to see they will include teaching help to use the CRS from theCGP.

b. Stephen said that GPO has no immediate short-term interest in the OCLC Member MergeProject

c. See FDLP 3R Project link: https://www.fdlp.gov/project-list /the-new-version-of-resource -description-and-access-rda -gpo-s-preparations-and-impacts -on-the-fdlp-community

3. Marcive Update (Jim Noel, Marcive, Inc. / CRDP)

a. Have been continuing the extension of the FTP file expiration to 45 days with an added 15 days to the expiration of all files in the system during the COVID19 outbreak for libraries in the CRDP program and those with Marcivesubscriptions.

b. Have been holding onto records especially for print documents, since GPO has suspended physically shipments and shipping lists and many libraries were not opened to receive these shipments.

4. Library of Congress Update (Dawn Rapoza, LC)

a. Updates on BIBFRAMEhttps://www.loc.gov/bibframe /docs/index.html

b. Updates on LOC State Government Websites of the US Archives: https://www.loc.gov /websites/?fa=partof:state+govern ment+websites+of+the+united+sta tes+web+archive\&q

5. PPM Chapter 14 Cataloging Committee 2019 Revision is NOT yet posted at the GODORTwebsite

a. Chair Andie C. to send note to Vicki Tate with a few morecorrections.

b. Chair Andie C. to ask Technology Committee to add the Cataloging Toolboxes Working Group names under the Cataloging Committee in the directory to show who is responsible and get them included on committee webpage.

6. Steering CommitteeUpdates

a. Reminder of Western States

Government Information Virtual Conference August 5-6, 2020https://www.colorado.edu /libraries/libraries/norlin-library /government-information-library /western-states-government -information

i. Andrea Morrison and James Rodgers announced that the Indiana Government Information Day follows right after on August 6 and 7, 2020, is now open for registration: https://www.in.gov/library/ GID.htm\#:-:text=Registration $\% 20$ is $\% 20$ now $\% 20$ open $\% 20$ for,earn $\% 20 L E U s \% 20$ for $\% 20$ each $\% 20$ session

7. Updates on the 3 Cataloging Toolbox LibGuides—https://godort.lib guides.com/cataloging

a. The Cataloging Toolboxes LibGuides need more volunteers for both the Cataloging Toolboxes for both International Government Information and for State Government Information. Approved updating this language for the Federal and Internationaltoolkits

"This Toolbox is currently under construction. We welcome your feedback and interest!"

The OECD Section of the International Toolbox is new and needs a volunteer editor.

b. Suggestion was made to include last update date on each Toolboxpage

c. Simon Healey is continuing work with Accessibility with the WAVE Web Accessibility Tool and with Springshare as Ex Officiomember.

d. Jim Noel agreed to be a contact and editor for all 3 Toolboxes as Ex Officiomember.

8. RDA Cataloging Standard Update \& CC:DA Report-RDA: Resource Description and Access (Andrea Morrison)

a. CC:DA is meeting July 9, July 13 , and July 15 in 2-hour virtual sessions. Andrea M. is planning on attending these meetings and submitting a written report. 
Meetings will be open to the public, but there will belimited space. https://alcts.ala.org /ccdablog/?cat=33.

- Thursday, July 9th: 3:00-5:00 Eastern/12:00-2:00 Pacific

- Monday, July 13th: 2:00-4:00 Eastern/11:00am-1:00 Pacific

- Wednesday, July 15th: 1:003:00 Eastern/10:00am-12:00 Pacific

b. The beta RDA Toolkit, which will be official this fall on December 15, 2020: http://www .rda-rsc.org/node/627

- The Cataloger's Learning Workshop overs free online training and education: https://www.loc.gov /catworkshop/

- Library of Congress Subject Headings: Online Training: https://www.loc.gov /catworkshop/lcsh/

- Preparing for the New RDA: RDA Toolkit Restructure and Redesign Project (3R Project) training on the new conceptual model, IFLA Library Reference Model, which replaces the FRBR family of models. "What is IFLA/LRM?": https://www.loc.gov/catwork shop/RDA2020/index.html

- RDA Toolkit YouTube channel has many free training webinars, from RDA vocabularies, entities, concepts, and elements, to tours of the beta RDA Toolkit, https://www .youtube.com/channel/UCd 5pa3AoQIr17wESE9YHcnw

c. OCLC Quality Control has posted June 2020 meetings on changes to Encoding Levels, see
https://help.oclc.org/WorldCat /Metadata_Quality/AskQC. Andrea M. reported that she can merge OCLC Connexion (WorldCat) duplicate bibliographic records that are provisional/brief monograph records to the GPO record. Stephen K. also confirmed that GPO reports duplicate records to OCLC formerging.

d. Andrea Morrison will roll off as CC:DA liaison but will continue as chair of the working group for the 3 Cataloging Toolboxes and report back to the Committee. Still need a new CC:DA liaison for term 2020-2023.

9. Committee continuing work on organizing or promoting already existing webinars or tutorials on cataloging Federal Documents, on weeding SuDocs, etc. First working on a Survey to be sent out to solicit more feedback on types of topics attendees would be interestedin.

\section{Report of the GODORT Government Information for Children Committee Virtual ALA Annual Meeting}

The GODORT Government Information for Children Committee concentrated its work this year on completing the migration of the GIC LibGuides from the former site hosted by the University of Central Florida to the GODORT LibGuides site. For 20202021, the committee looks forward to creating a Voter and Elections LibGuide aimed at students and children and to promoting the LibGuides, the Constitution Day Poster Contest, and the National History Day Poster Contest. At the virtual meeting for ALA Annual took place Monday, June 29, 3:30-4:15pm EDT, the committee reviewed the work on the LibGuides, discussed assigning a new representative to the Advisory Council for National History Day, and initiated discussion of the committee's plans for the new year.

\section{Report of the GODORT Government Information for Children Committee Virtual ALA Annual Meeting}

The GODORT Government Information for Children Committee concentrated its work this year on completing the migration of the GIC LibGuides from the former site hosted by the University of Central Florida to the GODORT LibGuides site. For 20202021, the committee looks forward to creating a Voter and Elections LibGuide aimed at students and children and to promoting the LibGuides, the Constitution Day Poster Contest, and the National History Day Poster Contest. At the virtual meeting for ALA Annual took place Monday, June 29, 3:304:15pm EDT, the committee reviewed the work on the LibGuides, discussed assigning a new representative to the Advisory Council for National History Day, and initiated discussion of the committee's plans for the new year.

\section{Education Committee}

At the summer virtual meeting, the Education Committee discussed ongoing work on the Voting \& Election Toolkits https://godort.libguides.com /votingtoolkit. The toolkits will be continually updated through the 2020 fall election and members discussed how to best keep the guide accurate during a dynamic election season where states are dealing with COVID-19 closures. The guide has been viewed over 6,000 times and content has been reused by a dozen 
librarians. The committee will continue promotion efforts into the fall.

The committee also discussed what new projects should be undertaken in the coming year. Support was expressed for developing a serious of educational short courses on government information. The committee also agreed to coordinate the creation of a Racism in Government research guide, with help from broader GODORT membership. Further prioritization of projects will be discussed at follow-up committee meetings._Kian Flynn

\section{Awards Committee}

GODORT honored the recipients of its 2019 awards at the virtual GODORT Awards Reception on Thursday July 2, 2020. Recipients of this year's awards are:

ProQuest/GODORT/ALA “Documents to the People" Award: Jacquelyn Daniel

Margaret T. Lane / Virginia F. Saunders Readex Memorial Research

Award: Dr. Martin Halbert, Roberta

Sittel, Dr.Katherine Skinner, Deborah Caldwell, Marie Concannon, James R.
Jacobs, Shari Laster, and Scott Matheson for Toward a Shared Agenda: Report on PEGI Project Activities for 2017-2019, published at https://educopia.org /pegi-toward-a-shared-agenda/

\section{W. David Rozkuszka Scholarship: Samantha Reardon}

The Awards Committee extends congratulations to the 2020 Awardees! For more information, please view the press release: http://www.ala.org/rt/2020 -godort-award-winners.—Laurie Aycock, Awards Chair 